\title{
Does Nigeria Non-Renewable Resource Abundance Leads to Macroeconomic Performance? A Trend Analysis (1970-2014)
}

\author{
Felix Odunayo Ajayi, A. Oluwaseyi Adelowokan, Oluwatosin O. Ogunyomi*
}

Department of Economics, Olabisi Onabanjo University, Ago-Iwoye, Ogun State, NIGERIA

*Corresponding Contact:

Email: tunjipeace6@gmail.com

Manuscript Received: 26 May 2019

Accepted: 10 Oct 2021

\begin{abstract}
Theoretically, natural resource abundance is expected to create national wealth; however, the inconclusiveness in the literature and among the African rich resources motivated this study. Our paper investigated that does Nigeria's non-renewable resource abundance leads to sustainable macroeconomic performance? To achieve the objectives of this study, our paper employs descriptive trends analysis, using tables and charts to measure the relationship between the non-renewable resource abundance, proxies as oil and gas variables, and the selected macroeconomic variables to draw an inference within the study period of 1970 - 2014 in Nigeria. In summary, our study concludes that an inverse relationship exists between non-renewable resource abundance and macroeconomic performance in Nigeria for the covered period 1970 - 2014. Therefore, our study conforms to the existing studies of Sachs \& Warner, 2001; Gylfason, 2005, Van der Ploeg and Venables, 2013 that African rich-resources countries, including Nigeria, a non-renewable resource abundance retards macroeconomic performance within the period of study. Nonetheless, this study recommends that government should consistently endeavor to increase the proportion of education expenditure to total expenditure as well as same for capital expenditure to total expenditure, and finally, transform the economy from an oil-dependent economy to a non-oil driven economy, that is diversification of the economy, which would change the non-renewable resource-abundant nation from curse to blessing and thus, guarantee sustainable macroeconomic performance in Nigeria.
\end{abstract}

Keywords: Non-renewable resource abundance, Sustainable macroeconomic, Trend analysis

This article is is licensed under a Creative Commons Attribution-NonCommercial 4.0 International License.

Attribution-NonCommercial (CC BY-NC) license lets others remix, tweak, and build upon work non-commercially, and

although the new works must also acknowledge \& be non-commercial.

\section{INTRODUCTION}

Over decades the relationship between non-renewable resource abundance and economic development has degenerated into inconclusive debates among development economists, policymakers and in the literature. Historically, the earlier works of the classical 
economists led by Adam Smith (1776) in His book title" The Nature and Causes of Wealth of Nations in 1776" advocated that natural resources play a significant role in economic development determinant of a nation. This advocacy was supported in the works of Lewis (1978), Maddison (1995), and Findlay \& Lundahl (1999).

Contrary to above preposition, recent studies have observed that resource- poor countries often outperform resource-rich countries in economic growth (DeLong and Williamson, 1994; Sachs and Warner, 1995a). The famous prominent empirical work carried out by Sachs and Warner (1995b) shows an inverse association between natural resources abundance and economic growth in a large cross-country data analysis. Also, Auty (1997, 2001) explains the root causes of resource-curse hypothesis that countries with abundance of natural resources (like oil, diamond, gold and other minerals) have less economic growth countries than do not possess these natural resources. For example, resource poor Netherlands eclipsed Spain, despite the overflow of gold and silver in the $17^{\text {th }}$ century. Also, in $19^{\text {th }}$ Century and $20^{\text {th }}$ century, resource poor countries such as Switzerland and Japan surged ahead of resource-abundant economies such as Russia. While in the past thirty years, the World's star performers have been the resource-poor newly industrializing economies of East Asia, fondly called Asian tigers - Korea, Taiwan \& Hong Kong had surpassed most African endowed resource countries like Angola, Nigeria and others.

In Africa context, African countries was ranked the world's third largest oil reserves, with an estimate of $9.5 \%$ global oil and gas reserves, behind the middle east $(61 \%)$ and North America $(11.6 \%)$. Further, in the area of renewable resources, the African continent hold at least 15 percent of the global gold reserves, and about 60 percent of the world's uncultivated arable land in Africa (Weaber and Wassermann, 2013).

Nonetheless, studies found that most African rich-resource countries, including Nigeria exhibits resource-curse characteristics, sometimes referred to as "Dutch-Diseases" and other syndrome (see Gylfasson, Herbertsson \& Zoega, 1999; Sachs \& Warner, 2001; Van der Ploeg and Poelhekke, 2009 and Van der Ploeg and Venables, 2013. These characteristics are excessive borrowing, corruption, government complacency, a neglect of education, de-industrialization, macroeconomic volatility, declining per capita GDP growth rate and above all violent uprisings and stagnated growth, rather than growth sustainability (Gylfason, 2005).

Specifically, Nigeria became the fourth country member of organization of petroleum exporting countries (OPEC) in 1971 and also the second Africa country member, after Algeria who joined OPEC in 1969. Thereafter, Nigeria was categorized as one of the richresource country with abundance of natural resources, of both renewable and nonrenewable resources. Further, Nigeria is the Africa highest oil exporter and the world's twelfth largest crude oil producing country (Ushie et al., 2012; OPEC bulletin, 2013). In addition, Nigeria is ranked $8^{\text {th }}$ and $4^{\text {th }}$ among the largest refinery capacity in world and as OPEC member country (OPEC, bulletin, 2013: 38 - 40). In same vein, Nigeria has realized over US $\$ 600$ billion from oil \& gas revenues since 1960, a figure greater than the resources used by the Marshall plan in rebuilding Europe after world War II but trapped in retrogressive and stagnated growth in real GDP and per capita GDP for over three decades. Unfortunately, by year 2010, Nigeria was ranked $142^{\text {nd }}$ out of 169 countries by the United Nations Human development Index, as the most corrupt practices country. Also, the National Bureau statistics (2012) also confirmed that more than $70 \%$ of Nigerians lived below the national poverty line (Ushie et al., 2012). 
Following the inconclusive existing studies on the relationship between natural resources and economic performance and the divergence from the classical economics development theory, it becomes pertinent to raise a salient question that "Is there any relationship between natural resource abundance and economic performance? And if any, what type of relationship exists? To this ends, our study aims to investigate the relationship between non-renewable resource abundance and economic performance in Nigeria within 1970 and 2018. Unlike previous studies, the non-renewable resource is limited to oil and gas sector and the selected macroeconomic variables in this study. In addition, the study employs a descriptive trends analysis, using table and charts for inference on the non-renewable resource abundance and sustainable economic performance in Nigeria from 1970 - 2014.

The rest of the paper is organized as follows. Section 2 presents the literature review on the subject matter. Section 3 presents the graphical trends analysis of oil and gas abundant resources performance and growth sustainability indicators in Nigeria for covered period, 1970-2014. Finally, section 4 provides conclusion and recommendations for the study.

\section{LITERATURE REVIEW}

The empirical study on this subject matter for a longer period had reached on consensus that abundant rich countries results to poor economic growth. Therefore, four theoretical literatures were used to channels the causation between abundant natural resources and poor growth has been identified (see Isham et al., 2003a; Isham et al., 2003b). However, in the most recent literature carried out using advance econometric techniques, found a contrary review on the Sachs \& Warner (1995) postulations.

Therefore, the four theoretical economic key linkages between natural resources and economic growth as explained in recent literature are as follows:

Firstly, natural resource abundance can lead to the Dutch-Disease, which can appear in several guises. A natural resource boom and the associated surge in raw materials exports can drive up the real exchange rate of the currency, thus possibly reducing manufacturing and service exports (Corden, 1984). Recurrent booms and burst tend to increase exchange rate volatility (Gylfason and Herbertsson, 1996; Herbertsson et al., 1999), thus reducing investment in the tradable sector as well as exports and imports of goods and services (see Dixit and Pindyck, 1994). Also, the Dutch-Diseases can be experienced with reduce total exports relative GNP (Gylfason, 2005). This may skew the composition of exports away from manufacturing and service exports which may contribute more to economic growth. Thus, this causes negative effect of de-industrialization on economic growth.

The second channel of causation is the relationship between natural resource abundance and rent seeking behavior. Empirically, it was found that in most developing countries, huge natural resources degenerated into ill-defined property rights, imperfect or missing markets and lax legal structures, thus leads to diversion of these rents away from more socially fruitful economic activity (Auty, 2001). Further, the works of Tornell \& Lane (1999) found that trade windfalls and natural resources booms trigger political interaction and resulted in current account deficits, disproportionate fiscal redistribution and reduced growth. In extreme cases, civil wars break out- such as Africa's diamond wars in SierraLeone and even recent the oil Niger-Delta Militant Groups in Nigeria. Therefore, the works of Collier and Hoeffler (2005) show empirically that natural resource abundance increases the probability of civil war. Also, Knight et al. (1996) show that abundance of natural resources prompt foreign governments to invade and leads to destructive 
consequences of domestic authorities spending vast resources on national defense, which inhibits capital formation and resource allocation.

Third, natural resources abundance has often reduce private and public incentives to accumulate human capital due to a high level of non- wage income, such as dividends, social spending, and low taxes. According to Gylfason and Herbertsson (1996) using a cross-country date established that an inverse relationship between school enrolment at all levels and natural resource abundance, measured as the share of the labour force engaged in primary production. Also, Gylfason and Zoega (2002) across countries found that public expenditure on education related to natural capital. In similarly findings like Temple (1999) shows that economic growth varies directly with educational attainment across countries sample. Therefore, the question of causality remains clear that abundant natural resources may reduce the demand for training and education. However, Botswana had been exception, for the rents stream from abundant natural resources resulted in a high priority to education.

Finally, the fourth channel of causation from natural resources to growth identified in the economic literature is that an abundant natural resource exposes such countries to macroeconomic volatility. According to Sachs and Warner (1999) and Rodriguez and Sachs (1999), they postulated that abundant natural resources may imbue people with a false sense of security and lead government to lose sight of the need for good and growth friendly economic management, including free trade, bureaucratic efficiency, institutional quality and above sustainable development. From this perspectives, Burno and Easterly (1998) and Gylfason and Herbertsson (1996), postulate that high inflation reflects flawed policies or weak institution associated with compliancy of abundant resources may impede growth sustainability. That is, Manna from heaven can be a mixed blessing (see Easterly, 2000).

Interestingly, the above four theoretical economic literatures on natural resource abundance had been directly related to poor growth rate as well as shortcut with bivariate cross- sectional relationships study. Also, all the theoretical economic literatures on natural resources abundance on economic growth, devoid the endogeneity growth model which could optimizes the natural resources abundance for a growth sustainability in both developed and developing countries.

However, more recent study, like Brunnschweiler \& Bulte (2008) evaluated the empirical basis of the resource curse using two-stage least squares (2SLS) estimation for a cross country sample of 60 countries using data from 1970 to 2000. The study concluded that export dependence does not affect economic growth but rather oil resource abundance positively affects per capita growth. Further, a similar related studies like Ding \& Field (2005), Brunnschweiler (2008) and Butkiewicz and Yanikkaya (2010) all found that export dependence does not bring economic curse but prosperity.

In same vein but different methodology, Adu (2010) investigated the relationship between long-run economic growth and natural resources abundance in Ghana, using a time series econometric techniques. This study differs from previous studies using nine indicators to proxy resource abundance. The result rejected the resource curse hypothesis, as only one out of the nine alternative measures consistently show negative, while others were positively related to long run economic growth. In conclusion, the study suggested reasons for growth collapse due to policy distortions, particularly in the agricultural section, trade restriction and growing government consumption. 
In the study of Ibrahim (2008), growth prospects of oil and gas abundant economies: the Nigerian experience from 1970 to 2000, concludes that it is obvious from the trends that increasing revenue accruing from the export of extracted oil \&gas does not necessarily translate to growth in the Nigerian economy. However, he suggested that for sustainable economic growth is essential for the country to expand her domestic markets, increase absorptive capacity and efficient utilization of factors of production through technological progress. Also, Ushie et al., (2012) in their empirical findings using VAR econometric modeling conclude that Nigerian economy suffers from Dutch - Disease syndrome due to over dependence on oil revenues. Therefore, they suggested that to eliminate oil revenues volatility, a more pragmatic macroeconomic policy, including fiscal and monetary policy should be targeted.

\section{Descriptive Trend Analysis}

\section{Crude Oil Performance in Nigeria}

Table 1: Annual Trends in Growth Rate of Crude Oil Production, Consumption, Export and Reserves in Nigeria (1970-2014)

\begin{tabular}{|c|c|c|c|c|c|c|c|c|}
\hline Year & $\begin{array}{c}\text { Crude Oil } \\
\text { Production }\end{array}$ & $\begin{array}{c}\text { Crude Oil } \\
\text { Production } \\
\text { Growth } \\
\end{array}$ & \begin{tabular}{|c|} 
Crude \\
Oil \\
Export
\end{tabular} & $\begin{array}{l}\text { Crude } \\
\text { Oil } \\
\text { Export } \\
\text { Growth }\end{array}$ & $\begin{array}{c}\text { Crude Oil } \\
\text { Domestic } \\
\text { Consumption }\end{array}$ & $\begin{array}{c}\text { Crude Oil } \\
\text { Domestic } \\
\text { Consumption } \\
\text { Growth }\end{array}$ & $\begin{array}{c}\text { Crude } \\
\text { Oil } \\
\text { Reserves }\end{array}$ & \begin{tabular}{|c|} 
Crude Oil \\
Reserves \\
Growth \\
\end{tabular} \\
\hline 1970 & 395 & & 384 & & 11 & & 9.3 & \\
\hline 1971 & 558 & 41.27 & 543 & 41.41 & 15 & 36.36 & 11.7 & 25.81 \\
\hline 1972 & 665 & 19.18 & 651 & 19.89 & 14 & -6.67 & 15 & 28.21 \\
\hline 1973 & 750 & 12.78 & 725 & 11.37 & 25 & 78.57 & 20 & 33.33 \\
\hline 1974 & 823 & 9.73 & 796 & 9.79 & 27 & 8 & 20.9 & 4.5 \\
\hline 1975 & 652 & -20.78 & 628 & -21.11 & 24 & -11.11 & 20 & -4.31 \\
\hline 1976 & 758 & 16.26 & 737 & 17.36 & 21 & -12.5 & 19.4 & -3 \\
\hline 1977 & 766 & 1.06 & 744 & 0.95 & 22 & 4.76 & 18.7 & -3.61 \\
\hline 1978 & 692 & -9.66 & 667 & -10.35 & 25 & 13.64 & 18.2 & -2.67 \\
\hline 1979 & 841 & 21.53 & 819 & 22.79 & 22 & -12 & 17.4 & -4.40 \\
\hline 1980 & 752 & -10.58 & 700 & -14.53 & 52 & 136.36 & 16.7 & -4.02 \\
\hline 1981 & 526 & -30.05 & 448 & -36 & 78 & 50 & 16.5 & -1.20 \\
\hline 1982 & 471 & -10.46 & 366 & -18.30 & 105 & 34.62 & 16.8 & 1.82 \\
\hline 1983 & 451 & -4.25 & 341 & -6.83 & 110 & 4.76 & 16.6 & -1.19 \\
\hline 1984 & 508 & 12.64 & 400 & 17.30 & 108 & -1.82 & 16.7 & 0.60 \\
\hline 1985 & 504 & -0.79 & 454 & 13.5 & 50 & -53.70 & 16.1 & -3.59 \\
\hline 1986 & 535 & 6.15 & 446 & -1.76 & 89 & 78 & 16 & -0.62 \\
\hline 1987 & 483 & -9.72 & 389 & -12.78 & 94 & 5.62 & 16 & 0 \\
\hline 1988 & 490 & 1.45 & 406 & 4.37 & 84 & -10.64 & 16 & 0 \\
\hline 1989 & 626 & 27.76 & 557 & 37.19 & 69 & -17.86 & 16 & 0 \\
\hline 1990 & 630 & 0.64 & 566 & 1.62 & 64 & -7.25 & 17 & 6.25 \\
\hline 1991 & 691 & 9.68 & 588 & 3.89 & 103 & 60.94 & 16.7 & -1.76 \\
\hline 1992 & 716 & 3.62 & 580 & -1.36 & 136 & 32.03 & 17.5 & 4.79 \\
\hline 1993 & 695 & -2.93 & 568 & -2.07 & 127 & -6.62 & 20.3 & 16 \\
\hline 1994 & 665 & -4.32 & 580 & 2.11 & 85 & -33.07 & 22.6 & 11.33 \\
\hline 1995 & 673 & 1.20 & 608 & 4.83 & 65 & -23.53 & 22.2 & -1.77 \\
\hline 1996 & 682 & 1.34 & 620 & 1.97 & 62 & -4.62 & 24.9 & 12.16 \\
\hline 1997 & 855 & 25.37 & 768 & 23.87 & 87 & 40.32 & 27.4 & 10.04 \\
\hline 1998 & 806 & -5.73 & 706 & -8.07 & 100 & 14.94 & 27.9 & 1.82 \\
\hline 1999 & 775 & -3.85 & 678 & -3.97 & 97 & -3 & 28.2 & 1.07 \\
\hline
\end{tabular}


Ajayi et al.: Daes Nigeria Non-Renewable Resaurce Abundance Leads to Macraeconomic Performance? A Trend Analysis (1970-2014) (13I-146)

\begin{tabular}{|c|c|c|c|c|c|c|c|c|}
\hline 2000 & 823 & 6.19 & 714 & 5.31 & 109 & 12.37 & 28.2 & 0 \\
\hline 2001 & 865 & 5.10 & 775 & 8.54 & 90 & -17.43 & 31.5 & 11.70 \\
\hline 2002 & 741 & -14.34 & 663 & -14.45 & 78 & -13.33 & 34.3 & 8.89 \\
\hline 2003 & 884 & 19.30 & 796 & 20.06 & 88 & 12.82 & 35.3 & 2.92 \\
\hline 2004 & 910 & 2.94 & 878 & 10.30 & 32 & -63.63 & 35.9 & 1.70 \\
\hline 2005 & 919 & 0.99 & 844 & -3.87 & 75 & 134.37 & 36.2 & 0.84 \\
\hline 2006 & 870 & -5.33 & 818 & -3.08 & 52 & -30.66 & 37.2 & 2.76 \\
\hline 2007 & 803 & -7.70 & 792 & -3.18 & 11 & -78.84 & 37.2 & 0 \\
\hline 2008 & 769 & -4.23 & 724 & -8.59 & 45 & 309.09 & 37.2 & 0 \\
\hline 2009 & 780 & 1.43 & 769 & 6.22 & 11 & -75.55 & 37.2 & 0 \\
\hline 2010 & 896 & 14.87 & 865 & 12.48 & 31 & 181.81 & 37.2 & 0 \\
\hline 2011 & 866 & -3.35 & 822 & -4.97 & 44 & 41.93 & 37.2 & 0 \\
\hline 2012 & 853 & -1.50 & 831 & 1.09 & 22 & -50 & 37.1 & -0.27 \\
\hline 2013 & 800 & -6.21 & 762 & -8.30 & 38 & 72.72 & 37.1 & 0 \\
\hline 2014 & 799 & -0.13 & 797 & 4.59 & 2 & -94.73 & 37.1 & 0 \\
\hline
\end{tabular}

Note: Crude Oil Production, Crude Oil Export and Crude Oil Domestic Consumption are in millions barrels per calendar day only, while Crude Oil Reserves is in Billions per calendar day.

Source: NNPC Bulletin, 2014; NBS, 2010; OPEC Bulletin, 2015 and CBN, 2014

Table 2: Interval Trends in Crude Oil Production, Export, Consumption and Reserves in Nigeria

\begin{tabular}{|c|c|c|c|c|}
\hline & $\begin{array}{c}\text { Crude Oil Production } \\
\text { (Average) }\end{array}$ & $\begin{array}{c}\text { Crude Oil Export } \\
\text { (Average) }\end{array}$ & $\begin{array}{c}\text { Crude Oil Domestic } \\
\text { Consumption (Average) }\end{array}$ & $\begin{array}{c}\text { Crude Oil Reserves } \\
\text { (Average) }\end{array}$ \\
\hline $1970-1980$ & 632.7 & 672.2 & 23.5 & 17.03 \\
\hline $1981-1990$ & 522.4 & 437.3 & 85.1 & 16.37 \\
\hline $1991-2000$ & 738.1 & 641 & 97.1 & 23.59 \\
\hline $2001-2010$ & 843.7 & 792.4 & 51.3 & 35.29 \\
\hline $2011-2014$ & 829.5 & 803 & 26.5 & 37.13 \\
\hline
\end{tabular}

Source: Authors computation, 2019

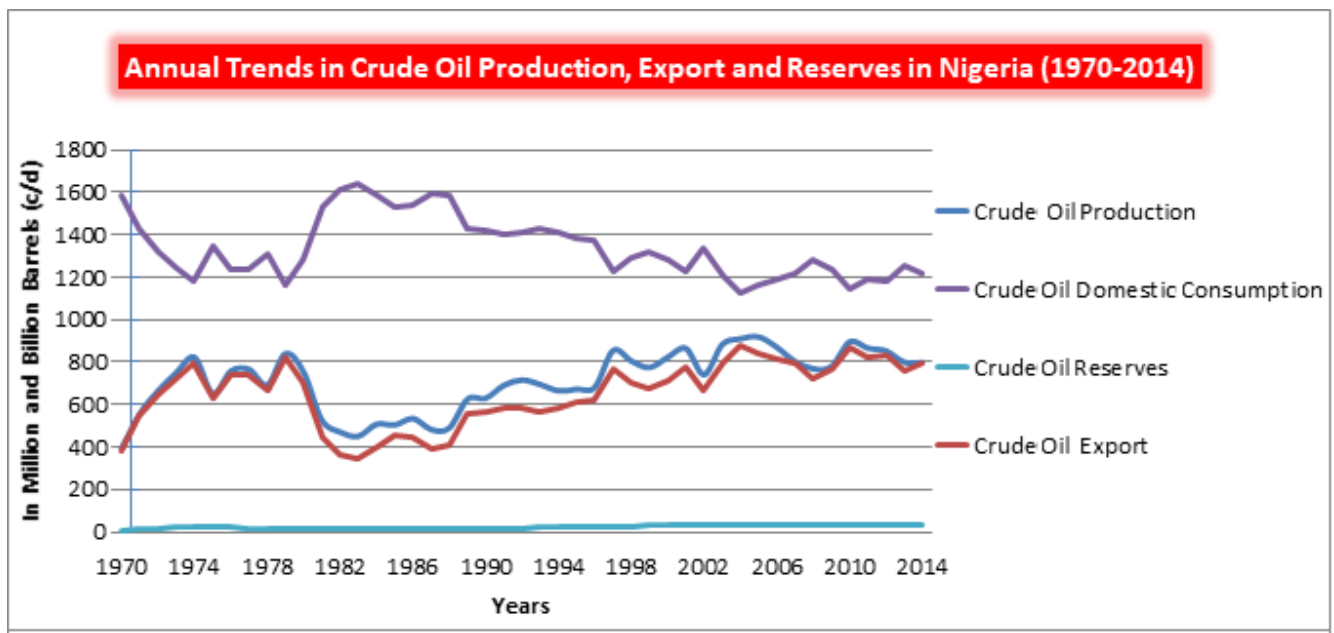

Figure 1: Annual Trends in Crude Oil Production, Consumption, Export and Reserves in Nigeria (1970-2014)

Source: Authors Chart, 2019 


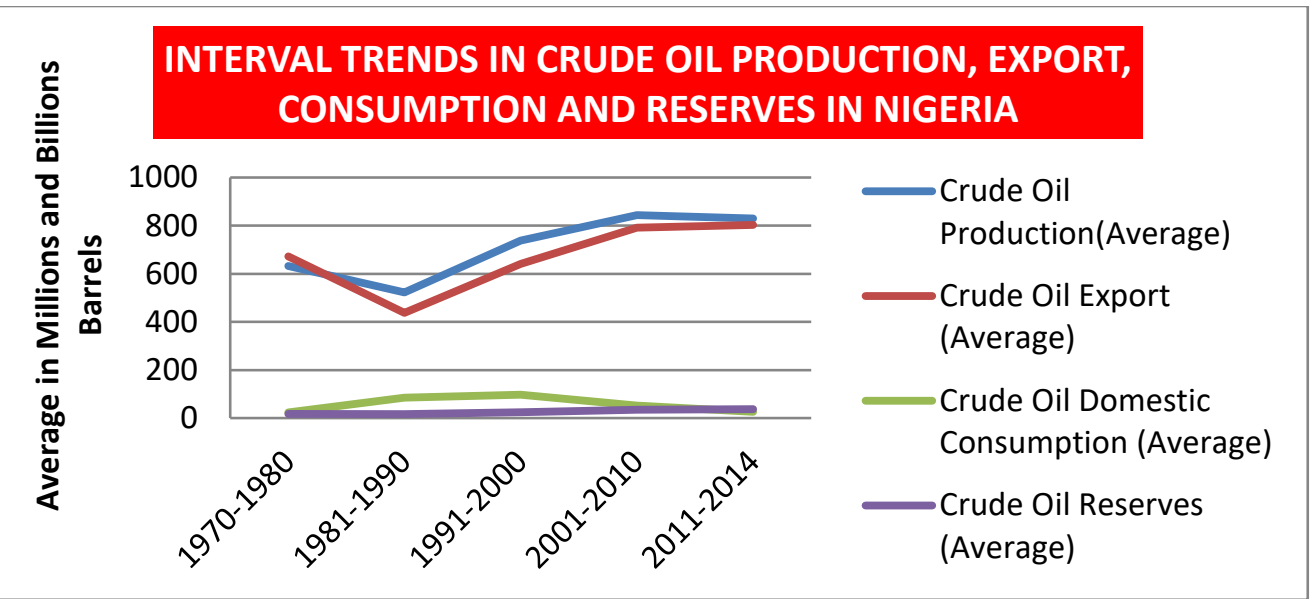

Figure 2: Interval Trends in Crude Oil Production, Export, Consumption and Reserves in Nigeria

Source: Authors Chart, 2019

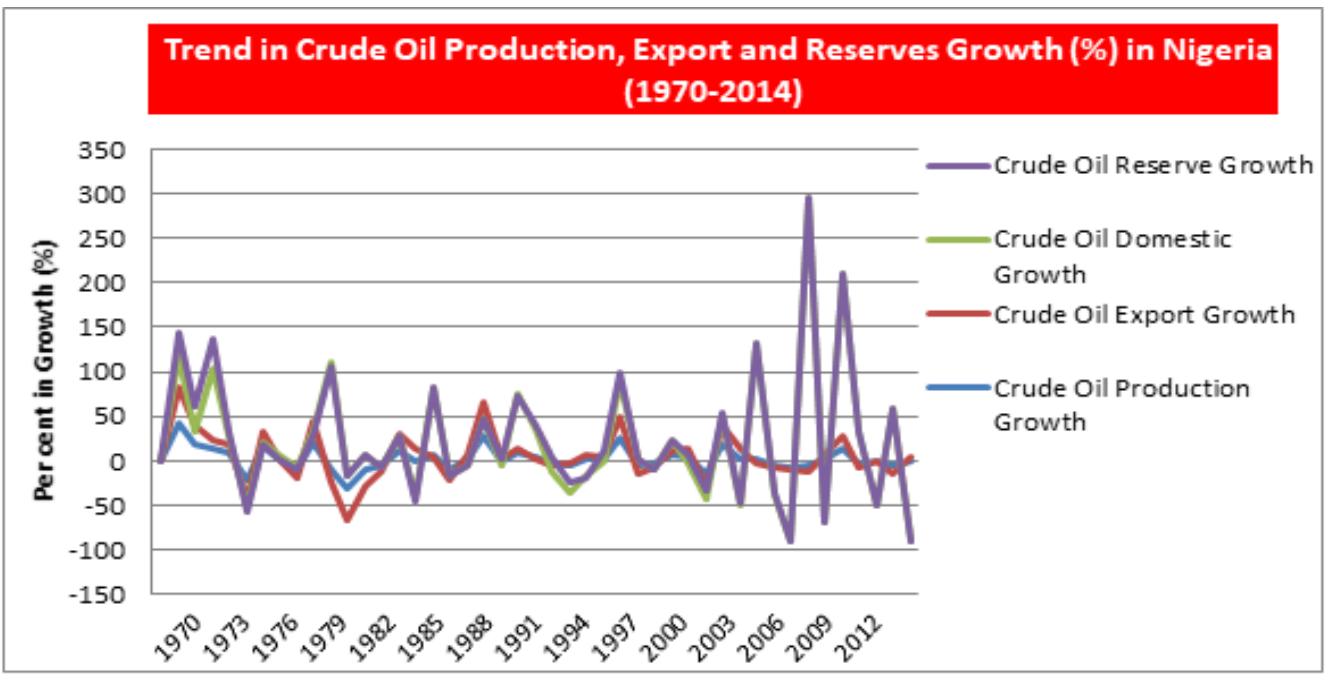

Figure 3: Trend in Crude Oil Production, Consumption, Export and Reserves Growth Per cent in Nigeria (1970-2014)

Source: Authors Chart, 2019

Table 1 and 2 exhibit annual and interval trend in crude oil performance in Nigeria between 1970 and 2014. Specifically, table 1 consists of eight columns excluding the year column, show the annual crude oil petroleum, export, domestic consumption and reserves as well as their respective growth rate for the period $1970-2014$. While table 2 shows 10 year average crude oil production, export, domestic consumption and reserves, excluding 1970 - 1980 and 2011 - 2014 shows varying average years of 11 year and 4 year respectively. More importantly, table 2 reveals that all the crude oil variables exhibit average increasing trends except for the period 1981 - 1990. Also, between 1970 and 2010, crude oil domestic consumption exhibits average increasing trends but decline in the last interval years, $2011-2014$, unlike others. 
Further, figure $1-3$ demonstrates the graphical trends analysis of table $1-2$. Specifically, figure 1 shows the graphical annual trends of the included crude oil variables for the period 1970 - 2014. More importantly, the figure 1 reveals that all the included crude oil variables are relatively volatile for the covered period. Below 1982, the figure 1 reveals that there was high volatility among variables, implying inconsistency in the included crude oil variables performance. Nonetheless, between 1982-2014, it shows that all the included crude oil variables were relatively less volatile and also exhibit a remarkable rising trend, excluding crude oil domestic consumption which was nose-diving, after the highest consumption peak in 1983. Finally, it also reveals that of all the crude oil variables, crude oil export was lower than others, implying the least oil performance variable within the study period.

Also, figure 2 exhibits interval trends analysis of the included crude oil variables performance in Nigeria. Before 1981-1990, there was a sharp fall in crude oil production and export respectively, while it was the opposite for others. Between 1990-2010, an uprising trends were experienced for crude oil production and export, while a relative rise was same for crude oil reserves but crude oil domestic consumption was stagnated and latter continually fell for the period 2011 - 2014. In same vein, between 2011- 2014, all the included crude oil variables experienced relative stagnation in Nigeria.

Finally, figure 3 demonstrates the growth rate of the included crude oil variables for the covered period 1970 - 2014, showing persistent volatile trends among the crude oil variables in Nigeria, implying an unpredictable and inconsistent behavior of the crude oil growth performance. Surprisingly, crude oil reserve growth is most volatile at a decreasing rate and the least volatile is crude oil production growth rate, followed by export and domestic growth, all approaching zero level.

In summary, the above tables and figures conclude that crude oil performance in Nigeria is largely unstable and poorly performed within the study $1970-2014$.

\section{Gas Performance in Nigeria}

Table 3: Annual Trend in Growth Rate of Gas Production, Utilization, and Reserves in Nigeria (1970-2014)

\begin{tabular}{|c|c|c|c|c|c|c|c|c|}
\hline Year & $\begin{array}{c}\text { Gas } \\
\text { Production }\end{array}$ & $\begin{array}{c}\text { Gas } \\
\text { Utilized }\end{array}$ & $\begin{array}{c}\text { Gas } \\
\text { Flared }\end{array}$ & $\begin{array}{c}\text { Gas } \\
\text { Reserves }\end{array}$ & $\begin{array}{c}\text { Gas } \\
\text { Production } \\
\text { Growth }\end{array}$ & $\begin{array}{c}\text { Gas } \\
\text { Utilized } \\
\text { Growth }\end{array}$ & $\begin{array}{c}\text { Gas } \\
\text { Flared } \\
\text { Growth }\end{array}$ & $\begin{array}{c}\text { Gas } \\
\text { Reserves } \\
\text { Growth }\end{array}$ \\
\hline 1970 & 8 & 0.1 & 7.9 & na & & & & \\
\hline 1971 & 12 & 0.22 & 11.78 & na & 50 & 120 & 49.11 & na \\
\hline 1972 & 17 & 0.23 & 16.77 & na & 41.67 & 4.55 & 42.36 & na \\
\hline 1973 & 22 & 0.4 & 21.6 & na & 29.41 & 73.91 & 28.80 & na \\
\hline 1974 & 27 & 0.39 & 26.61 & na & 22.73 & -2.5 & 23.19 & na \\
\hline 1975 & 19 & 0.32 & 18.68 & na & -29.63 & -17.95 & -29.80 & na \\
\hline 1976 & 21 & 0.66 & 20.34 & na & 10.53 & 106.25 & 8.89 & na \\
\hline 1977 & 22 & 0.87 & 21.13 & na & 4.76 & 31.82 & 3.88 & na \\
\hline 1978 & 20 & 1.05 & 18.95 & na & -9.09 & 20.69 & -10.32 & na \\
\hline 1979 & 27 & 1.38 & 25.62 & na & 35 & 31.43 & 35.20 & na \\
\hline 1980 & 25 & 2.34 & 22.66 & na & -7.41 & 69.57 & -11.55 & na \\
\hline 1981 & 17 & 3.64 & 13.36 & na & -32 & 55.56 & -41.04 & na \\
\hline 1982 & 15 & 3.44 & 11.56 & na & -11.76 & -5.50 & -13.47 & na \\
\hline 1983 & 15 & 3.24 & 11.76 & na & 0 & -5.81 & 1.73 & na \\
\hline 1984 & 16 & 3.44 & 12.56 & na & 6.67 & 6.17 & 6.80 & na \\
\hline
\end{tabular}


ABC Jaurnal of Advanced Research, Volume ID, № 2 (20ZI)

ISSN 2304-2621(p); 2312-203X(e)

\begin{tabular}{|c|c|c|c|c|c|c|c|c|}
\hline 1985 & 19 & 4.65 & 14.35 & na & 18.75 & 35.17 & 14.25 & na \\
\hline 1986 & 19 & 4.82 & 14.18 & na & 0 & 3.66 & -1.18 & na \\
\hline 1987 & 17 & 4.98 & 12.02 & na & -10.53 & 3.32 & -15.23 & na \\
\hline 1988 & 20 & 5.51 & 14.49 & 2476 & 17.65 & 10.64 & 20.55 & na \\
\hline 1989 & 25 & 6.3 & 18.7 & 2832 & 25 & 14.34 & 29.05 & 14.38 \\
\hline 1990 & 28 & 6.02 & 21.98 & 2840 & 12 & -4.44 & 17.54 & 0.28 \\
\hline 1991 & 31 & 6.8 & 24.2 & 3400 & 10.71 & 12.96 & 10.10 & 19.72 \\
\hline 1992 & 32 & 7.58 & 24.42 & 3716 & 3.23 & 11.47 & 0.91 & 9.29 \\
\hline 1993 & 34 & 7.91 & 26.09 & 3683 & 6.25 & 4.35 & 6.84 & -0.89 \\
\hline 1994 & 34 & 6.77 & 27.23 & 3450 & 0 & -14.41 & 4.37 & -6.33 \\
\hline 1995 & 35 & 8.11 & 26.89 & 3474 & 2.94 & 19.79 & -1.25 & 0.70 \\
\hline 1996 & 35 & 8.86 & 26.14 & 3475 & 0 & 9.25 & -2.79 & 0.03 \\
\hline 1997 & 37 & 10.38 & 26.62 & 3483 & 5.71 & 17.16 & 1.84 & 0.23 \\
\hline 1998 & 37 & 13.41 & 23.59 & 3512 & 0 & 29.19 & -11.38 & 0.83 \\
\hline 1999 & 44 & 21.27 & 22.73 & 3512 & 18.92 & 58.61 & -3.65 & 0 \\
\hline 2000 & 43 & 18.48 & 24.52 & 4106 & -2.27 & -13.12 & 7.88 & 16.91 \\
\hline 2001 & 58 & 14.9 & 43.1 & 4633 & 34.88 & -19.37 & 75.77 & 12.83 \\
\hline 2002 & 101 & 16 & 85 & 4997 & 74.14 & 7.38 & 97.22 & 7.86 \\
\hline 2003 & 53 & 19 & 34 & 5055 & -47.52 & 18.75 & -60 & 1.16 \\
\hline 2004 & 70 & 22.39 & 47.61 & 5229 & 32.08 & 17.84 & 40.03 & 3.44 \\
\hline 2005 & 58 & 22.4 & 35.6 & 5125 & -17.14 & 0.04 & -25.23 & -1.99 \\
\hline 2006 & 58 & 28.5 & 29.5 & 5207 & 0 & 27.23 & -17.13 & 1.6 \\
\hline 2007 & 68 & 32.5 & 35.5 & 5292 & 17.24 & 14.04 & 20.34 & 1.63 \\
\hline 2008 & 73 & 32.83 & 40.17 & 5292 & 7.35 & 1.02 & 13.15 & 0 \\
\hline 2009 & 57 & 23.21 & 33.79 & 5110 & -21.92 & -29.30 & -15.88 & -3.44 \\
\hline 2010 & 72 & 28.1 & 43.9 & 5154 & 26.32 & 21.07 & 29.92 & 0.86 \\
\hline 2011 & 84 & 41.32 & 42.68 & 5118 & 16.67 & 47.05 & -2.78 & -0.70 \\
\hline 2012 & 85 & 42.57 & 42.43 & 5111 & 1.19 & 3.03 & -0.59 & -0.14 \\
\hline 2013 & 80 & 38.41 & 41.59 & 5111 & -5.88 & -9.77 & -1.98 & 0 \\
\hline 2014 & 86 & 43.84 & 42.16 & 5111 & 7.5 & 14.14 & 1.37 & 0 \\
\hline
\end{tabular}

Note: Gas Production, Gas Utilized and Gas Flared are in millions barrels per calendar day only, while Gas Reserves is in billions per calendar day. na-Not Available

Source: NNPC Bulletin, 2014; NBS, 2010; OPEC Bulletin, 2015 and CBN, 2014

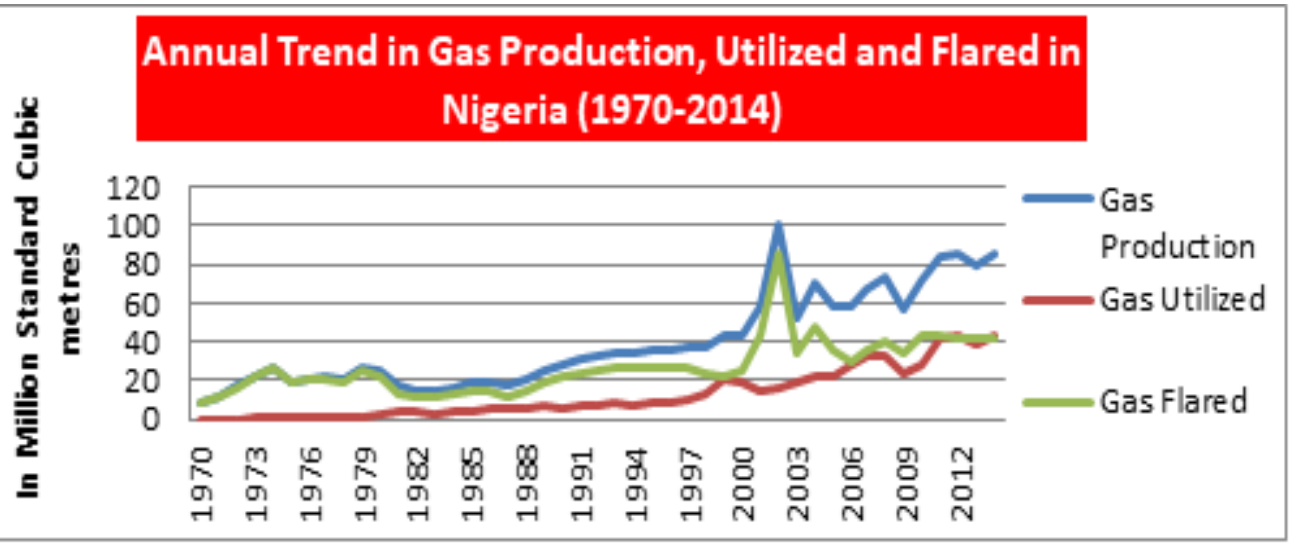

Figure 4: Graphical Annual Trends in Gas Production, Utilization and Flared in Nigeria (1970-2014) 
Table 4: Interval Trends in Gas Production, Utilized and Reserves in Nigeria

\begin{tabular}{|c|c|c|c|}
\hline Years & Gas Production (Average) & Gas Utilized (Average) & Gas Reserves (Average) \\
\hline $1970-1980$ & 20 & 0.21 & na \\
\hline $1981-1990$ & 19.1 & 4.6 & na \\
\hline $1991-2000$ & 36.2 & 10.96 & 25.24 \\
\hline $2001-2010$ & 66.8 & 23.98 & 42.82 \\
\hline $2011-2014$ & 83.75 & -41.54 & 42.22 \\
\hline
\end{tabular}

Source: Authors computation, 2019

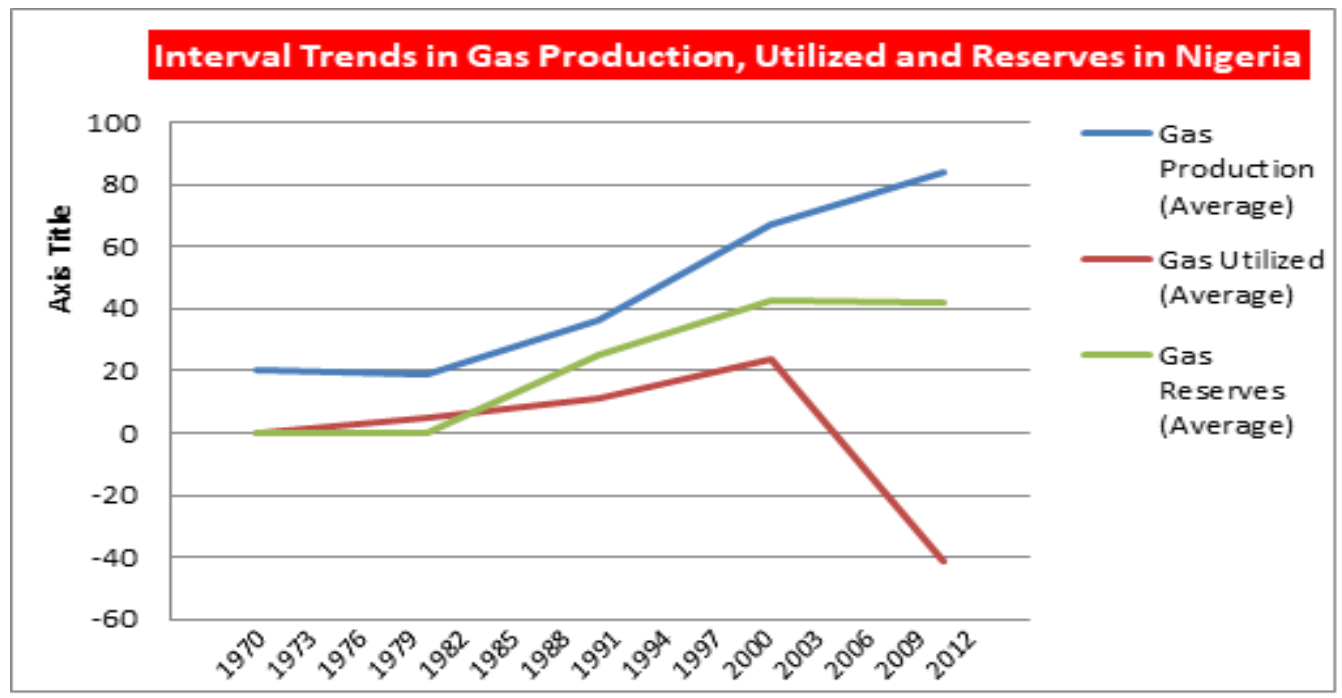

Figure 5: Graphical Interval Trends in Gas Production, Utilized and Reserves in Nigeria Source: Authors Chart, 2019

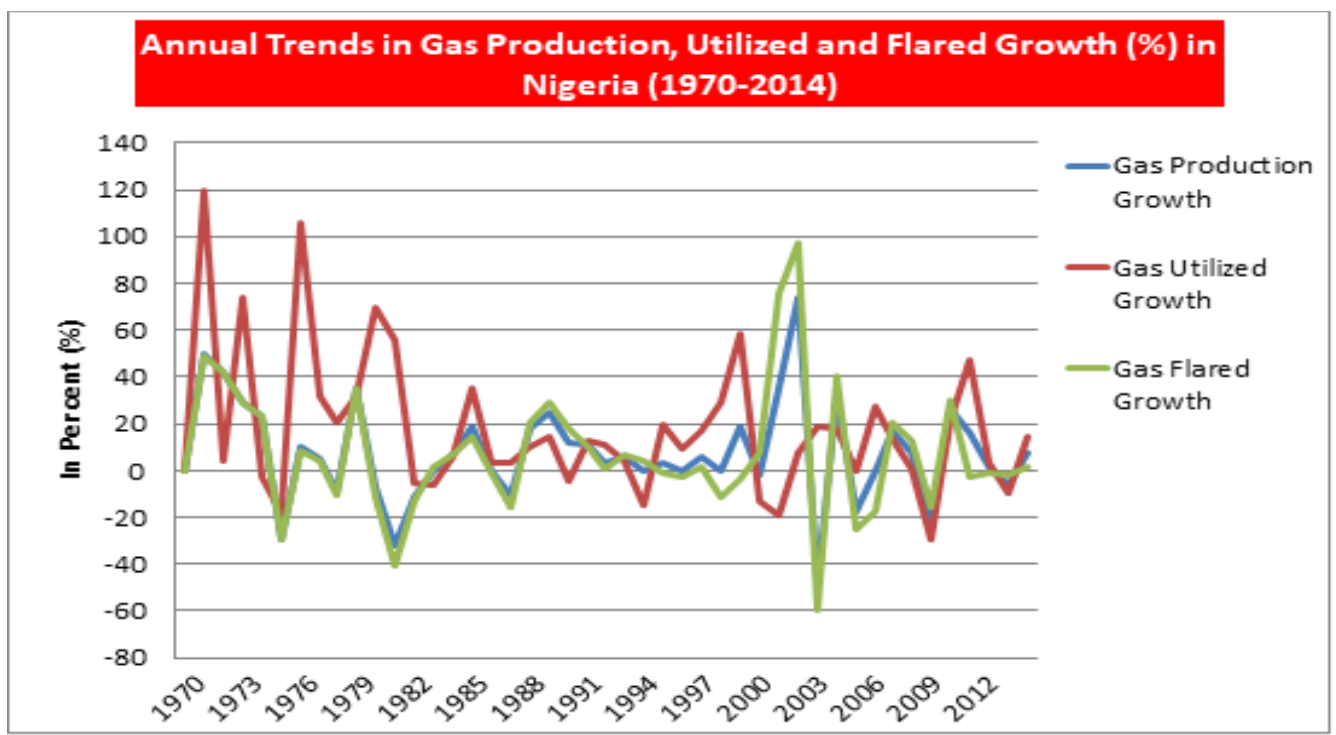

Figure 6: Graphical Annual Trends in Gas Production, Utilization and Flared Growth per cent in Nigeria (1970-2014)

Source: Authors Chart, 2019 
As shown in table 3 and 4, the annual and interval average trends in gas production, utilized and reserves respectively for the covered period $1970-2014$. In addition, table 4 shows the 10 year average trends excluding 1970 - 1980 and $2011-2014$, which are 11 year and 4 year average trends respectively.

Further, figure $4-6$ exhibits the graphical analysis of the dataset in table 3 and 4 . Specifically, figure 4 shows that all the included gas variables have an increasing trends for the covered period $1970-2014$.

More importantly, the annual gas production trends was persistently above annual gas flared and utilized trends and in addition, annual gas utilized trends was least below in figure 4. This implies that gas utilization for the period $1970-2014$ is at least optimal in Nigeria. Also, figure 5 shows the graphical interval trends in gas production, utilized and reserves in Nigeria. Specifically, between 1970 - 1980 and 1981 - 1990, there was stagnated growth rate in average gas production and reserves respectively, excluding average gas utilization which exhibits increasing trends in same period. Surprisingly, all the included gas variables show an average increasing trend between $1991-2000$. However, all but average gas production witnessed a continuous increasing interval trends from 2001-2010 to 2011-2014, while average gas utilized and reserves interval trends experienced a sharp fall and stagnation respectively. This results support the conclusion in figure 4 and also reiterate the government leadership between 2001-2010 and 2011- 2014, did little or nothing to improve the gas sector performance, unlike previous administrations interval years.

In summary, the result shown in table 3 and 4 as well as figure $4-6$, concludes that the abundant gas resources performance is underutilized and relatively unstable for the covered period 1970-2014 in Nigeria.

\section{Non-Renewable Resource Abundance and Economic Performance in Nigeria}

Table 4: Annual Trends in Total Non-Renewable Resources Abundance and Macroeconomic Variables in Nigeria (1970-2014)

\begin{tabular}{|c|c|c|c|c|c|c|c|}
\hline Year & $\begin{array}{c}\text { Total } \\
\text { Non-Renewable } \\
\text { Reserves } \\
\text { (Oil and Gas only) }\end{array}$ & $\begin{array}{c}\text { Total Non- } \\
\text { Renewable } \\
\text { Resources } \\
\text { Revenue (\% GDP) }\end{array}$ & $\begin{array}{c}\text { GDP } \\
\text { growth } \\
\text { Rate (\%) }\end{array}$ & PCI & INFL & $\begin{array}{c}\text { Export } \\
\text { on Non-oil } \\
\text { \% Total } \\
\text { Export) }\end{array}$ & $\begin{array}{c}\text { Total EDU } \\
\text { Exp (\%TGE) }\end{array}$ \\
\hline 1970 & 9.3 & 4.68 & & 0 & 13.8 & 42.38 & 0 \\
\hline 1971 & 11.7 & 11.11 & 0 & 0 & 16 & 26.32 & 0 \\
\hline 1972 & 15 & 10.57 & 0 & 0 & 3.2 & 17.98 & 0 \\
\hline 1973 & 20 & 15.17 & 0 & 0 & 5.4 & 16.89 & 0 \\
\hline 1974 & 20.9 & 36.41 & 0 & 0 & 13.4 & 7.40 & 0 \\
\hline 1975 & 20 & 24.98 & 0 & 0 & 33.9 & 7.35 & 0 \\
\hline 1976 & 19.4 & 24.68 & 0 & 0 & 21.2 & 6.36 & 0 \\
\hline 1977 & 18.7 & 27.73 & 0 & 0 & 15.4 & 7.31 & 8.39 \\
\hline 1978 & 18.2 & 25.27 & 0 & 0 & 16.6 & 10.93 & 7.13 \\
\hline 1979 & 17.4 & 55.93 & 0 & 0 & 11.8 & 6.18 & 12.18 \\
\hline 1980 & 16.7 & 42.66 & 0 & 2.19 & 10 & 3.91 & 10.37 \\
\hline 1981 & 16.5 & 30.19 & 0 & 2.11 & 21.4 & 3.11 & 8.59 \\
\hline 1982 & 16.8 & 29.51 & 1.81 & 2.1 & 7.2 & 2.47 & 9.54 \\
\hline 1983 & 16.6 & 36.5 & -1.19 & 2.05 & 23.2 & 4.01 & 10.03 \\
\hline 1984 & 16.7 & 48.12 & 0.60 & 1.98 & 40.7 & 2.72 & 8.71 \\
\hline 1985 & 16.1 & 47.49 & -3.59 & 1.87 & 4.7 & 4.24 & 6.52 \\
\hline
\end{tabular}


Ajayi et al.: Daes Nigeria Non-Renewable Resaurce Abundance Leads to Macroeconomic Performance? A Trend Analysis (1970-2014)

\begin{tabular}{|l|c|c|c|c|c|c|c|}
\hline 1986 & 16 & 32.94 & -0.62 & 1.81 & 5.4 & 6.18 & 6.73 \\
\hline 1987 & 16 & 34.01 & 0 & 1.75 & 10.2 & 7.09 & 2.95 \\
\hline 1988 & 18.48 & 30.91 & 15.5 & 1.98 & 56 & 8.84 & 4.75 \\
\hline 1989 & 18.83 & 42.03 & 1.89 & 1.96 & 50.5 & 5.09 & 4.73 \\
\hline 1990 & 15.84 & 46.24 & -15.88 & 1.61 & 7.5 & 2.96 & 3.80 \\
\hline 1991 & 20.1 & 44.51 & 26.89 & 2.01 & 12.7 & 3.84 & 2.34 \\
\hline 1992 & 21.22 & 41.7 & 5.57 & 2.06 & 44.8 & 2.06 & 2.22 \\
\hline 1993 & 23.98 & 67.69 & 13.01 & 2.26 & 57.2 & 2.28 & 4.18 \\
\hline 1994 & 22.95 & 55.99 & -4.29 & 2.12 & 57 & 2.59 & 6.39 \\
\hline 1995 & 25.67 & 40.66 & 11.85 & 2.31 & 72.9 & 2.42 & 5.11 \\
\hline 1996 & 28.38 & 43.83 & 10.56 & 2.48 & 29.3 & 1.78 & 4.55 \\
\hline 1997 & 30.83 & 43 & 8.63 & 2.63 & 8.5 & 2.35 & 3.72 \\
\hline 1998 & 31.41 & 29.62 & 1.88 & 2.61 & 10 & 4.53 & 5.49 \\
\hline 1999 & 31.71 & 32.99 & 0.95 & 2.57 & 6.6 & 1.64 & 3.33 \\
\hline 2000 & 32.31 & 47.36 & 1.89 & 2.56 & 6.9 & 1.28 & 9.63 \\
\hline 2001 & 36.13 & 44.17 & 11.82 & 2.80 & 18.97 & 1.50 & 5.87 \\
\hline 2002 & 35.3 & 29.14 & -2.29 & 2.65 & 12.88 & 5.43 & 10.75 \\
\hline 2003 & 40.36 & 35.97 & 14.33 & 2.96 & 14.03 & 3.07 & 6.48 \\
\hline 2004 & 41.13 & 38.31 & 1.90 & 2.93 & 15 & 2.46 & 6.57 \\
\hline 2005 & 41.33 & 43.86 & 0.48 & 2.83 & 17.86 & 1.46 & 6.58 \\
\hline 2006 & 42.41 & 39.33 & 2.61 & 2.88 & 8.23 & 1.82 & 8.52 \\
\hline 2007 & 42.5 & 35.82 & 0.21 & 2.81 & 5.39 & 2.39 & 6.15 \\
\hline 2008 & 42.49 & 38.09 & -0.023 & 2.74 & 11.58 & 2.43 & 6.57 \\
\hline 2009 & 42.31 & 26.63 & -0.42 & 2.64 & 12.54 & 3.46 & 5.23 \\
\hline 2010 & 42.35 & 18.05 & 0.09 & 2.58 & 13.74 & 3.59 & 6.16 \\
\hline 2011 & 42.32 & 20.35 & -0.07 & 2.50 & 10.83 & & 7.87 \\
\hline 2012 & 42.21 & 17.3 & -0.25 & 2.38 & 12.22 & & 7.56 \\
\hline 2013 & 42.21 & 8.49 & 0 & 2.31 & 8.5 & & 7.53 \\
\hline 2014 & 42.21 & 7.63 & 0 & 2.28 & & & 6.79 \\
\hline & & & & & & & \\
\hline
\end{tabular}

Note: All in per cent but total non-renewable resources and per capita income (PCI) are in barrels per calendar day and ratio values

Source: OPEC Bulletin, 2015; World Bank Database, 2013; and CBN Statistical Bulletin, 2006, 2014.

Table 4 above shows the annual trends of non-renewable resources abundance and the selected macroeconomic variables in Nigeria between 1970 and 2014. All variables were in percentage except total non-renewable resources and per capita income (PCI) expressed in values.

Figure 7 consists of $7 \mathrm{~A}-7 \mathrm{~F}$ to demonstrate each graphical trend of non-renewable resources abundance and the selected macroeconomics variables for the covered period 1970 - 2014. Specifically, each figure 7A to 7F explains the trends behavior between nonrenewable resource abundance and the macroeconomic variables and thus draw inference on the type of relationship in existence in Nigeria for the period $1970-2014$.

First, figure 7A shows the graphical trends between the non-renewable resources and the non-renewable resources revenue (\% GDP) for the period $1970-2014$. As shown in figure 7A, there was an opposite trending behavior between the two variables, the total nonrenewable resources exhibits a persistent increasing trend while the proportion of nonrenewable resources to GDP exhibit an inconsistent decreasing trends for the period 1970 2014. This concludes that in-spite of the abundant non-renewable resources; the income accrued from the non-renewable had contributed insignificantly to the total sector 
productivity in Nigeria for the period 1970 - 2014, thus, a negative relationship exist between non-renewable resource and nation wealth in Nigeria which is commonly characterized as resource-curse syndrome.

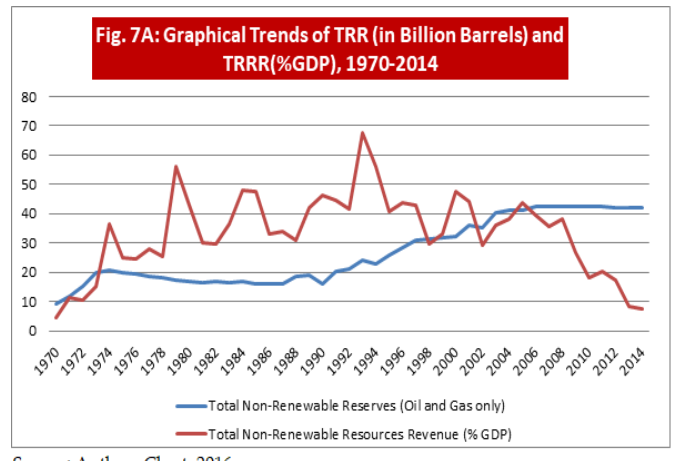

Source: Authors Chart, 2016
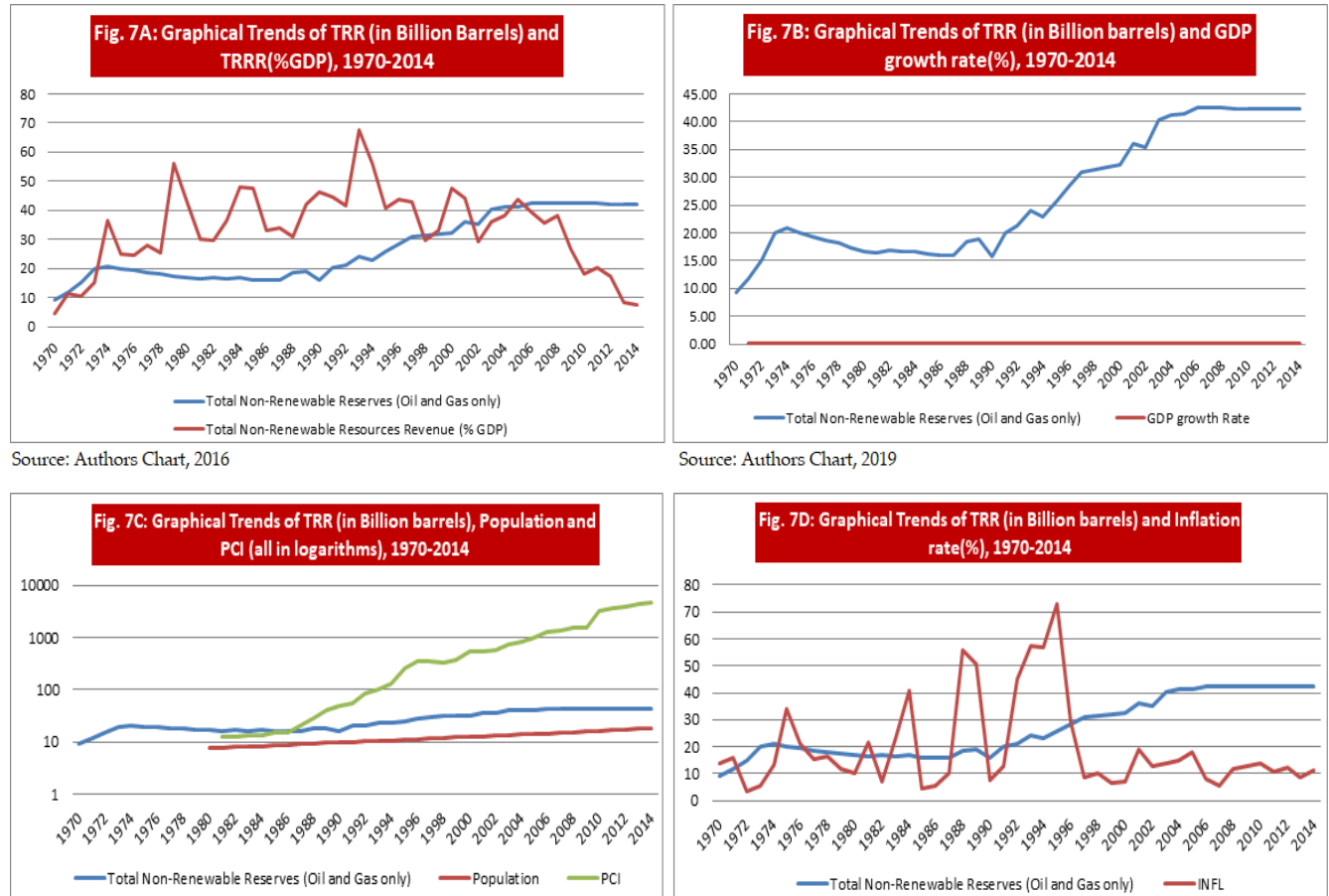

Source: Authors Chart, 2016
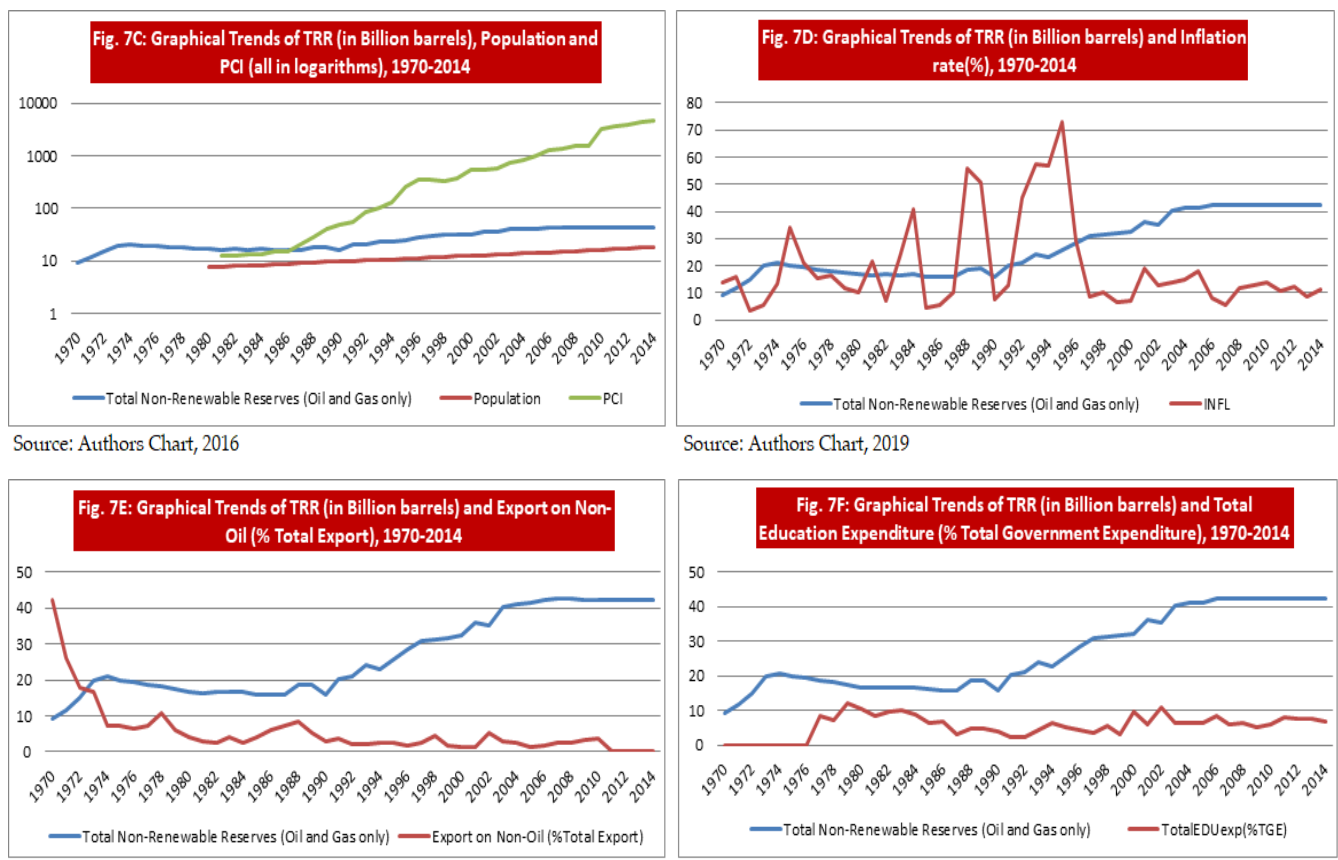

Soturce: Authors Chart, 2019

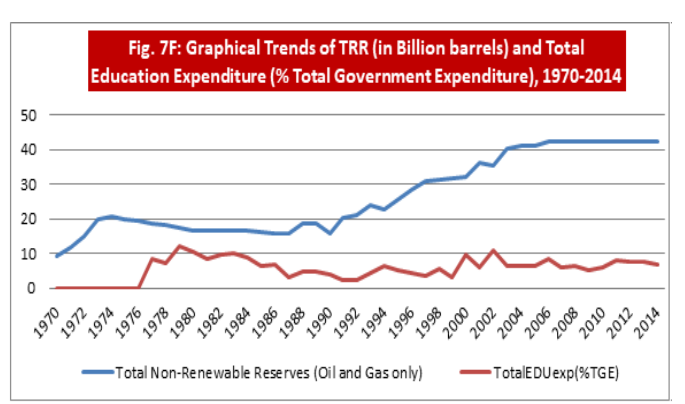

Source: Authors Chart, 2019

Source: Authors Chart, 2019

Figure 7: Graphical Annual Trends in non-renewable resources Abundance and the selected Macroeconomics Variables Performance in Nigeria: A Resource Curse Graphical Analysis (1970-2014)

Second, figure 7B exhibits graphical trends between abundant non-renewable resources and GDP growth rate for the covered period 1970 - 2014. As shown in the figure, it reveals that despite a continuous increasing trend in abundant non-renewable resources, the GDP growth rate had persistently remain stagnated for the covered period, $1970-2014$. This findings confirms that Nigeria is resource-curse, with stagnated and a very low insignificant GDP growth rate of less than 5 percent's despite persistent uprising abundant non-renewable resources. This implies a negative association exhibit between nonrenewable resource and GDP growth in Nigeria within 1970-2014. 
Also, figure 7C which shows the graphical analysis between total non-renewable abundant resources, population and PCI. It shows that all included variables are increasing trends but the maximum and minimum increasing trends are non-renewable abundant resources and this implies that the country, Nigeria abundant non-renewable resources are under-utilized, thus, retards the people standard of living in Nigeria within the study 1970 - 2014. Further, figure 7D also shows the graphical analysis between total non-renewable resources and inflation rate in for the period 1970 - 2014 in Nigeria. Evidently, only inflation rate exhibits unstable trends but remarkably a decreasing trends earmark from 1999-2014, unlike previous years. This implies that within period of study, there was price instability but more pronounced in 1994, during political unrest in Nigeria. More importantly, since the democratic era, the inflation rate had continually reduce with slight fluctuates between 1997-2014. In summary, the study concludes that despite abundant non-renewable resources, there was a relative high inflation rate experienced in Nigeria, and thus, characterized as a resource curse nation. Also, figure 7E shows the graphical trends relationship between total non-renewable abundant resources and the proportion of non-oil export to total export for the covered period $1970-2014$. As shown in the chart above, as the non-renewable abundant resources increases, the proportion of non-oil exports to total export continually declines and almost approaches zero, implying a poor real sector performance and heavy dependent oil sector economy. Therefore, with this attributes, Nigeria is an example of Dutch-diseases syndrome.

Finally, figure 7F also shows the graphical analysis of total non-renewable abundant resource and proportion of education expenditure to total government expenditure for the covered period 1970-2014. As shown above, the proportion of education expenditure to government expenditure had been relatively unchanged for the covered period. However, the highest proportion of education expenditure to government expenditure was experienced in 1979 and thereafter, continually declines was experienced from 1980-1999. This implies that there is a negative relationship between non-renewable resource abundance and education performance in Nigeria within 1970-2014 in this study.

With the table and graph results, it reveals that there is a negative relationship between non-renewable resource abundance and economic performance indicators in Nigeria within 1970-2014 in this study. .

\section{Conclusion And Recommendations}

Based on our findings, the study concludes that the Nigeria non-renewable resource abundance leads not to sustainable economic performance within 1970-2014, using trend analysis. That is, the included macroeconomic variables are in an opposite direction with the non-renewable resources (oil and gas) in Nigeria for the covered period $1970-2014$. Therefore, our study conform with the existing studies (Sachs \& Warner, 2001; Gylfason, 2005, Van der Ploeg and Venables, 2013) that African rich-resources countries, including Nigeria, a non-renewable resource abundance retards macroeconomic variables performance.

Nonetheless, this study recommends the following to change non-renewable resource abundance nation from curse into blessing as follows:

First, the government should increase education expenditure allocation, so as to efficiently utilize the abundant non-renewable resources to stimulate economic growth and 
guarantee sustained macroeconomic variables as reiterated by Gylfason (2005) and demonstrated by the Asia-tigers.

Second, the government should transform the economy from oil dependent economy to non-oil driven economy, that is, diversification of the economy to achieve magnitude increase in proportion of non-oil sector export to total export as well as proportion of total non-oil sector revenue to GDP in the country, as demonstrated by United Arab Emirates (UAE), diversifying from oil abundant resources into tourism, agricultural and manufacturing sectoral development.

Finally, the way out for Nigeria resource curse into blessing is to increase the proportion of capital expenditure to total government expenditure, so as to increases gross capital formation (infrastructure) and thereafter, reduces domestic inflation rate, increases employment opportunities and consolidate other monetary and fiscal policies towards the attainment of sustainable economic performance in the country, Nigeria.

\section{REFERENCES}

Adu, G. (2010). Natural resources abundance and economic growth: The case of Ghana, environment and resource economics unit, Department of Economics, Sweden, 1-39.

Auty, M. (1997). Resource abundance and economic development. Helsinki: UNU World Institute for Development Economic Research.

Auty, R. (2001). Resource abundance and economic development. Oxford University Press.

Brunnschweiler, C. N. (2008). Cursing the blessing? Natural resource abundance, institutions and economic growth, World Development, 36, 399-419

Brunnschweiler, C.N. and Bulte, E.H. (2008). The resource curse revisited and revised: A Tale of paradoxes and Red Herrings. Journal of Environmental Economics and Management, 55, 248-264

Burno, M. and Easterly, W. (1998). Inflation crises and long run growth. Journal of Monetary Economics, 41, 3-26.

Butkiewicz, J. L., and Yanikkaya, H. (2010). Minerals, institutions, openness and growth: An empirical analysis. Land Economics, 86, 313-328.

Collier, P. and Hoeffler, A. (2005). Democracy and resource rents, Working Paper, Oxford University.

Corden, W. M. (1984). Booming sector and Dutch-Disease Economics: Survey and consolidation. Oxford Economic Paper 36, 359-380.

DeLong, J. B. and Williamson, J. G. (1994). Natural resources and convergence, In: The Nineteenth and Twentieth Centuries, Unpublished paper, Harvard University.

Ding, N. and Field, B. C. (2005). Natural resource abundance and economic growth.Land Economics, 81, 496-502.

Dixit, A. K. and Pindyck, R. S. (1994). Investment under uncertainty. Princeton University Press.

Easterly, W. R. (2000). Growth imposition and debt explosions: Do growth slowdowns causes debt crises? World Bank Working Paper.

Findlay, R. and Lundahl, M. (2001). Natural resources and economic development: The 1870-1914, experience in R.M. Auty (ed.)., Resource abundance and economic development, Oxford University Press.

Gylfason, T. (2005). Natural resources, education and economic development. European Economic Review, May.

Gylfason, T. and Herbertsson, T. T. (1996). Does inflation matter for growth? CEPR Discussion Paper No. 1503, December. 
Gylfason, T. and Zoega, G. (2002). Natural resources and economic growth: The role of investment. Working Paper, No. 142, Central Bank of Chile.

Herbertsson, T. T., Skuladottir, M. G. and Zoega, G. (1999). Three symptoms and a cure: A contribution to the Economics of the Dutch-Disease. Institute of Economic Studies, University of Iceland, Working Paper No. W99:10.

Ibrahim, M. J. (2008). Growth prospects of oil and gas abundance economies: The Nigeria experience (1970-2000). Journal of Economic Studies, 35(2), 170-190.

Isham, J., Pritchett, L., Woolcock, M. and Busby, G. (2003a). The varieties of the resource experience: How natural resource export structures affect the political economy of economic growth, Mimeo, World Bank, Washington D.C.

Isham, J., Woolcock, M., Pritchett, L. and Busby, G. (2003b). The varieties of rentier experience: How natural resource export structures affect the political economy of economic growth. Middlebury College Economics Discussion paper 8.

Knight, M., Loayza, N. and Villanueva, D. (1996). The peace dividend: Military spending cuts and economic growth.

Lewis, W. A. (1978). Growth and fluctuations, 1870-1913. London: George Allen and Unwin.

Maddison, A. (1995). Monitoring the World economy: 1820-1922. Development Centre of the Organization for Economic Cooperation and Development, Paris.

OPEC. (2013). Annual OPEC statistical bulletin, 38-40.

Rodriguez, F. and Sachs, J. (1999). Why do resource abundant economies grow more slowly? Journal of Economic Growth, 4(3), 277-303.

Sachs, J. D. and Warner, A. M. (1995b). Natural resource abundance and economic growth, NBER Working paper, No. 5398, Cambridge, Massachusetts.

Sachs, J. D. and Warner, A. M. (1995a). Revised 1997 and 1999. Natural resource abundance and economic growth. National Bureau of Economic Research Working Paper 5398, Cambridge, MA.

Sachs, J. D. and Warner, A.M. (1999). The big push natural resource booms and growth. Journal of development Economic, 59, 43-76.

Sachs, J. D. and Warner, A.M. (2001). Natural resources and economic development: The curse of natural resources. European Economic Revieww, 45, 827-838.

Smith, A. (1776). An enquiry into the nature and causes of the wealth of nations. Oxford: Clarendon Press.

Temple, J. (1999). A positive effect of human capital on growth. Economics Letter, 65, 131-134.

Tornell, A. and Lane, P. (1999).Voracity and growth. American Economic Review, 89, 22-46.

Ushie, V., Adeniyi, O. and Akongwale, S. (2012). Oil revenues, institutions and macroeconomic performance in Nigeria. CSEA Working Paper, WPS/12/02, Abuja.

Van der Ploeg, F. and Poelhelkke, S. (2009). Volatility and the natural resource curse. Oxford Economic Policy, 61, 727-760.

Van der Ploeg, F. and Venables, A. J. (2013). Absorbing a windfall of foreign exchange: Dutch-disease dynamics. Journal of Development Economics, 103, 229-243.

Weaber, P. and Wassermann, N. (2013). Will Africa's natural resources lead to prosperity? http://www.Credit-suisse.com/ch/en/news-and-expertise/news.article.htm 